\title{
Water Footprint of Soybean, Maize and Wheat in Pergamino, Argentina
}

\section{Luciana Tozzini, Alejandro Pannunzio, Pamela Texeira Soria}

Eng. Irrigation and Drainage Section, School of Agronomy, University of Buenos Aires, Buenos Aires, Argentina

Email: tozzini@agro.uba.ar, pannunzio@agro.uba.ar, texeira@agro.uba.ar

How to cite this paper: Tozzini, L. Pannunzio, A. and Soria, P.T. (2021) Water Footprint of Soybean, Maize and Wheat in Pergamino, Argentina. Agricultural Sciences, 12, 305-323. https://doi.org/10.4236/as.2021.123020

Received: December 22, 2020

Accepted: March 28, 2021

Published: March 31, 2021

Copyright $\odot 2021$ by author(s) and Scientific Research Publishing Inc. This work is licensed under the Creative Commons Attribution International License (CC BY 4.0).

http://creativecommons.org/licenses/by/4.0/

\section{(c) (i) Open Access}

\begin{abstract}
Nowadays more than $70 \%$ of the fresh water available worldwide is used for agriculture. In Argentina, extensive crops are not usually irrigated, so the cropping production depends mostly on rainfall water. In order to know how many liters of water are needed to produce a ton of soybeans, wheat and maize in the Pergamino district, Province of Buenos Aires, its Water Footprint was estimated by the Hoekstra method. Evaporation and rainfall data was obtained from SIGA INTA platform and production data was obtained from the Ministry of Agriculture. The results indicated that the average annual total water footprint values for soybean, corn and wheat crops for the period 2013-2018 in the Pergamino district, province of Buenos Aires, are 1,388 $1 \cdot \mathrm{kg}^{-1}, 6931 \cdot \mathrm{kg}^{-1}$ and $1,249 \mathrm{l} \cdot \mathrm{kg}^{-1}$ respectively. These were lower than the global average reference values. The obtained results allowed future analysis advancing in the knowledge of the use of water productivity in grain production.
\end{abstract}

\section{Keywords}

Water Footprint, Pergamino, Soybean, Maize, Wheat

\section{Introduction}

In the near future, humanity will have to face many challenges. The access and availability of water as a basic requirement for life and ensuring that the extraction of fresh water does not affect ecosystems are among the most important [1]. With a projected potential population of 9.2 billion by 2050 as projected by the UN (2015), it's really important to ensure the food and plant biomass needs for future generations, especially in regions where water resources are limited [2].

Currently agriculture production uses approximately $70 \%$ of the fresh water available worldwide. Also, in many parts of the world, agriculture competes with 
other activities such as supplying urban settlements or the industrial activity for the use of water [3].

Increasing the productivity of water in agriculture ("more crop per drop") would mean reducing the water footprint (WF) per unit of production, and this could contribute to reduce the pressure of use on the world's freshwater resources [4].

$\mathrm{WF}$ is a quantifiable indicator that measures the volume of water consumed per unit produced of a good or service. It is the summary of blue water, green water, and grey water. The blue WF takes into account the volume of ground and surface water used to irrigate the crop. The green WF considers the volume of rainwater consumed by the crop in its growth period that is provided by rainwater effectively stored in the root depth soil. Grey WF refers to the volume of water required to assimilate fertilizers and pesticides that could run off or percolate reaching and contaminating both surface and underground water courses [5].

In Argentina, the total cultivated area shows, in recent years (1992-2018), a sustained growth (from 27.80 million hectares in 1992 to 32.7 million hectares in 2018), with a particular boost since 2002. The Irrigated area has not accompanied the same growth rate, finding that only 1,391,074 hectares are irrigated throughout the country, of which 168,614 hectares are in the province of Buenos Aires [6]. This means $0.51 \%$ of the currently cultivated area (32.7 million ha), represents a growth rate lower than the trends in other regions and other Latin American countries. Extensive crops in Argentina are mostly produced in dryland so it's not usual to have water use efficiency records or information. Estimating parameters like the WF can be useful to establish agronomic and productive parameters and define management actions. In addition, it is essential to raise awareness about the amount of water used and the importance of water-related ecosystem services for production [7].

The WF provides information on trade flows in terms of water. According to Hoekstra, $16 \%$ of the water consumed in the world travels virtually from one country to another through products [8].

Pergamino is geographically located at the north of the province of Buenos Aires, as it can be seen in Figure 1. Its area is $2,950 \mathrm{~km}^{2}$ and has a population of 110,000 habitants. Approximately $86.5 \%$ of the population lives in its main urban centre, the city of Pergamino. The other towns of the district are smaller and concentrate $9 \%$ of the population in total. Approximately $4.5 \%$ of the total population of the district lives in rural areas [9].

The main economic activities in Pergamino are the manufacture of clothing, wood, plastics, food, metal, dairy, poultry production, tourism and agricultural production.

The region has a mild climate, with an annual average temperature of $15^{\circ} \mathrm{C}$ $\left(10^{\circ} \mathrm{C}\right.$ in winter and $22^{\circ} \mathrm{C}$ in summer). The average annual rainfall is $970 \mathrm{~mm}$. The driest months are in the winter and the wettest are in January and March. 

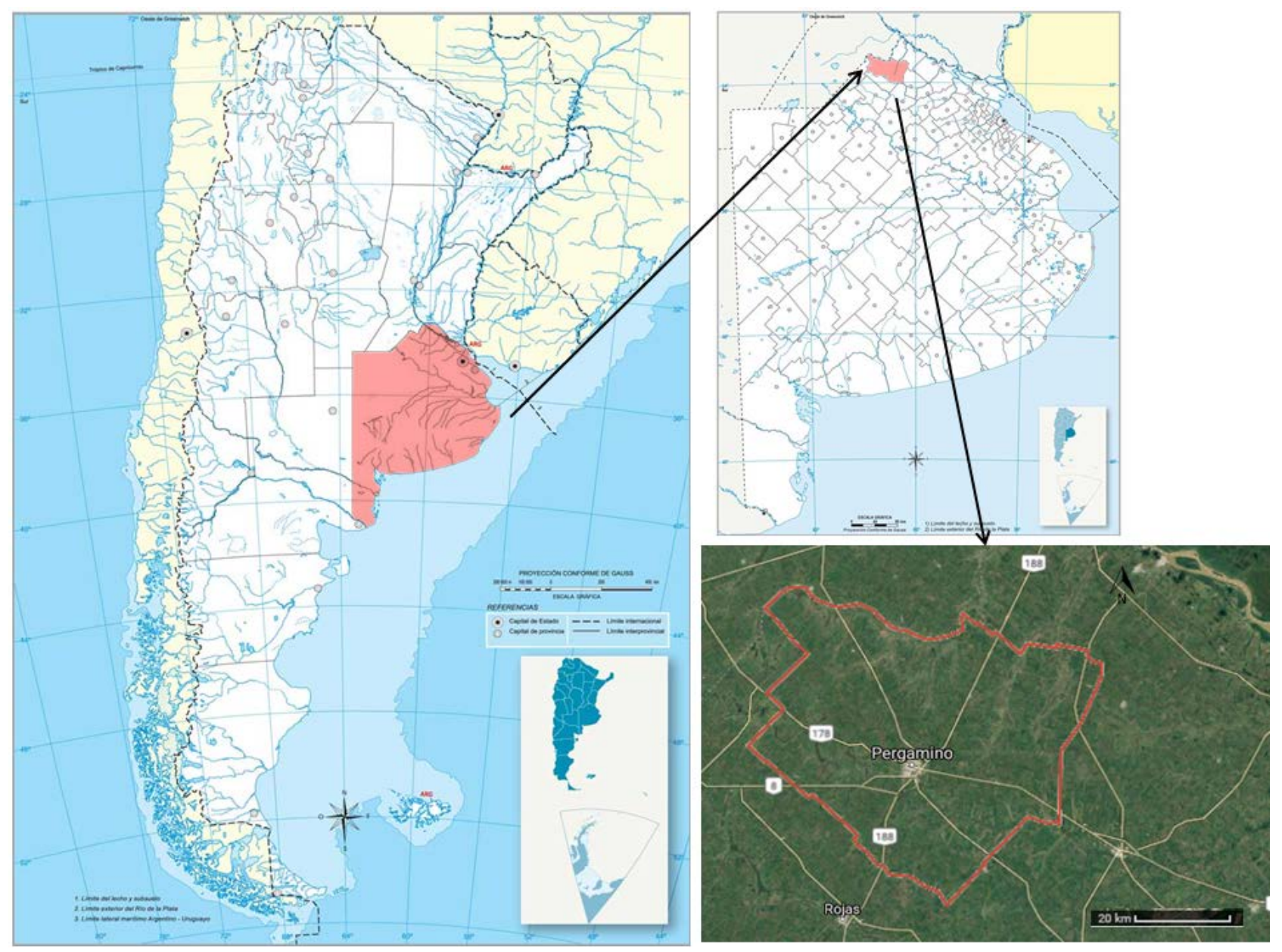

Figure 1. Pergamino district location.

The mean annual potential evapotranspiration is around $1,000 \mathrm{~mm}$. The irregularity in rainfall causes water deficits of different magnitudes to occur, generally in summer and in the last ten years there have been very wet cycles, followed by very dry cycles [10].

The cartographic units were represented by the dominant soil modal series. In total, eight series of soils suitable for mainly agricultural use were identified. At the taxonomic subgroup level, Typical Argiudoles prevail, followed by Typical Hapludoles and Natracuols. Eight series of soil make up the Arroyo Pergamino basin: Arrecifes (typical Argiudol), Arroyo Dulce (typical Argiudol), Gouin (Aquic Argiudol), Pergamino (typical Argiudol), Ramallo (Argiudol vertico), Rojas (typical Argiudol), Santa Lucía (Typical Natracuol) and Venado Tuerto (typical Hapludol) [11].

The Pergamino stream belongs to the Paraná river system and is located within the Arrecifes river basin. The region where it is located is called Pampa Ondulada, and it is characterized by a gently undulating relief and partly cut by ravines, streams and rivers. This watercourse is eroded and worn, incorporating a large quantity of particles, clay and calcareous material into its flow; increasing 
the sand content downstream. Likewise, it has a high content of salts from the soil [12].

There are two regions in the province of Buenos Aires where the process of water erosion is relevant with different degrees of occurrence: the Pampa Ondulada and the Pampa Serrana and Interserrana; 33\% of their lands are affected by this process [13].

This work seeks to estimate the water footprint for the most important grain crops, based on the surface they occupy in the Pergamino district, province of Buenos Aires, to determine the amount of water needed to produce a ton of grain. The objective of this study was to estimate the WF under rainfed conditions of corn, soybean and wheat crops in Pergamino in the period 2013-2018 to compare it with the global reference values. More specifically, it was sought to determine the monthly evapotranspiration of each of the three crops mentioned, calculate the effective precipitation for each of them from the precipitation that occurred and respective monthly evapotranspiration and compare the results obtained with the global reference results calculated by Mekonnen and Hoekstra in 2011 [14].

In Argentina, agricultural production is developed in 33.2 million hectares. The importance of the knowledge of the water footprint of the main crops produced is not only knowing the amount of the limited resource and the efficiency with which it is used, but it also makes it possible to assess the environmental impact of different applied production technologies. The knowledge of this environmental indicator makes recognition possible of the impacts of human activities in freshwater systems and can be related to consumption, and issues such as water scarcity and its pollution can be better understood and addressed if we consider value chains as a whole system. Also, it will help in optimal planning of future water under climate change in the agricultural sector.

\section{Methods}

The calculation of the WF of crops was done in several steps including the calculation of the: monthly evapotranspiration of each of the three crops mentioned, effective precipitation for each of them, green and grey WF from these results and then integrate all terms to estimate the total WF for each one.

\subsection{Calculation of the Monthly Evapotranspiration}

The water demand of each crop was estimated as the crop evapotranspiration (ETc) through the relationship between the reference evapotranspiration (ETo) and the crop coefficient $(\mathrm{Kc})$ according to the following formula endorsed by FAO in 2006:

Equation (1): ETc calculation, FAO, 2006

$$
E T c=E T o \times k c .
$$

The climatic data of potential evapotranspiration (ETp) from January 2013 to 
December 2018 were obtained from the Agrometeorological Information and Management System of INTA. The kc, typical for each crop and for each moment of its cycle, were obtained from FAO.

\subsection{Calculation of the Effective Precipitation}

The water contribution per crop is considered equal to the effective precipitation calculated by the methodology of the SCS (Soil Conservation Service) of the United States Department of Agriculture (USDA) [15]. The effective precipitation was adjusted by the storage capacity of the soil related to the depth of the crop roots. In addition, the characteristics of the region's soil were taken into account. The soil data was obtained from the INTA soil chart, Pergamino series. No limitations were found in the soils of the Pergamino series that could affect root growth, water infiltration or the storage capacity of the soil.

The climatic data of precipitation (Pp) from January 2013 to December 2018 were obtained from the Agrometeorological Information and Management System of INTA.

\subsection{Calculation of the Green WF}

The annual green WF was calculated, for the period 2013 to 2018, for soybean, corn and wheat crops in the Pergamino district, province of Buenos Aires, according to the formula proposed by Hoekstra and collaborators in 2011 [5]:

Equation (2): Green WF calculation, Hoekstra et al., 2011

$$
\text { Green WF }=\frac{\text { Water contribution per crop }(\mathrm{l} / \mathrm{ha})}{\text { Yield }(\mathrm{tn} / \mathrm{ha})} .
$$

The productive yield data for the crops under study was obtained from the reports of the Ministry of Agroindustry from the 2013/2014 season to the 2017/2018 season. Data on sown area, harvested area, production and yield were collected. The soybean, maize and wheat crops were selected based on their relevance in the area and the availability of data.

There was no information on the initial water content or the final water content of the soils at the time of the study. When calculating the soil water balance at a multi-year level, the term corresponding to the change in storage (S) was considered to take the value of 0 , because the variability of the water stored in the basin over long periods does not experience significant changes.

\subsection{Calculation of the Grey WF}

To calculate grey WF, the methodology proposed by Mekonnen and Hoekstra [16], was used. It considers the applied fertilizer as a pollutant load but does not include indirect pollution such as the use of fuel and energy, nor grey water associated with the agrochemicals used in the production. Grey water was calculated according to the formula proposed by Mekonen and Hoekstra in 2011 [16]:

Equation (2): Grey WF calculation, Mekonnen y Hoekstra, 2011. 


$$
\text { Grey } \mathrm{WF}=\frac{\mathrm{L}}{\mathrm{Cmax}-\mathrm{Cmin}} \times \mathrm{Y} \text {. }
$$

where:

- $\mathrm{L}=$ amount of nitrogen applied to the crop $\left(\mathrm{kg} \cdot \mathrm{ha}^{-1}\right)$.

- $\mathrm{Y}=$ crop yield $\left(\mathrm{kg} \cdot \mathrm{ha}^{-1}\right)$.

- $\mathrm{Cmax}=45 \mathrm{mg} \cdot \mathrm{l}^{-1}$ according to the Argentine Food Code.

- Cnat $=10 \mathrm{mg} \cdot \mathrm{l}^{-1}$ as maximum (in rural, non-urban) according to groundwater studies in the area (Puelche Pampean aquifer).

The methodology proposes to select the most used and most persistent agrochemical to recreate the worst possible situation. Nitrogen was used as the main pollution indicator. It isn't recommendable using phosphorus as an indicator of contamination of the aquifer due to its low mobility and high retention in the soil, added to the fact that the amounts of phosphorus applied are very low in the region. The application rate data (L) was obtained from the applied agricultural technology survey prepared by Bolsa de Cereales de Rosario [17]. The fertilizer input data was the average zonal doses by crop, zone and technological level. The average amount of nitrogen applied per hectare was the sum of the amount of nutrient provided by the various fertilizer sources used. The maximum nitrate content allowed by the CAA is $45 \mathrm{mg} \cdot \mathrm{l}^{-1}$ [18]. The ACUMAR Environmental Quality Coordination established that, as of 2012, wells with up to $10 \mathrm{mg} \cdot \mathrm{l}^{-1}$ of nitrates in rural areas predominate in the Puelche aquifer [19].

\subsection{Calculation of the Total WF}

The annual WF was calculated, for the period 2013 to 2018, for soybean, corn and wheat crops in the Pergamino district, province of Buenos Aires, according to the formula proposed by Hoekstra and collaborators in 2011 [5]:

Equation (3): WF calculation, Hoekstra et al., 2011.

$$
\mathrm{WF}=\text { Green } \mathrm{WF}+\text { Gray } \mathrm{WF}+\text { Blue WF . }
$$

The blue WF, which is the one that considers the contribution of irrigation water of superficial and subsurface origin, was not considered relevant in this study since the use of irrigation systems for grain production is less than $5 \%$ of the total surface according to the National Census (2018) and it is to be considered that many of the pressurized irrigation systems for grains are used for the seed production [6]. The average global WF data for the aforementioned crops were obtained from the Mekonnen and Hoekstra publication made in 2011, called "The Green, Blue and Gray Water Footprint of Crops and Derived Crop Products" [14].

\section{Results}

\subsection{Evapotranspiration and Rainfall (2013-2018)}

Monthly effective rainfall $\left(\mathrm{mm} \cdot \mathrm{month}^{-1}\right)$ was calculated for 5 years from the $2013 / 14$ growing season to the $2017 / 18$ growing season. A set of effective rainfall 
was calculated for each species, together with its net irrigation needs, according to the methodology of SCS (Soil Conservation Service) of the United States Department of Agriculture (USDA) [15], as detailed in materials and methods. Water supply was quantified through effective precipitation. It was $524 \mathrm{~mm}, 342$ $\mathrm{mm}$ and $259 \mathrm{~mm}$ for Soybean, maize and wheat respectively, on average per year, for the period considered. A relationship was established between the effective precipitation and the ETc, obtaining the net need for water. It reflects the quantity of missing water of the crop to complete its demand. Figure 2, Figure 3 and Figure 4 summarize the interannual differences of effective precipitation, crop evapotranspiration and water need for the mentioned crops. 1 As can be seen, net water requirements were not covered in any season, and in 2017 there was less annual precipitation. This was due to La Niña weather phenomenon, which led to a severe drought in the region.

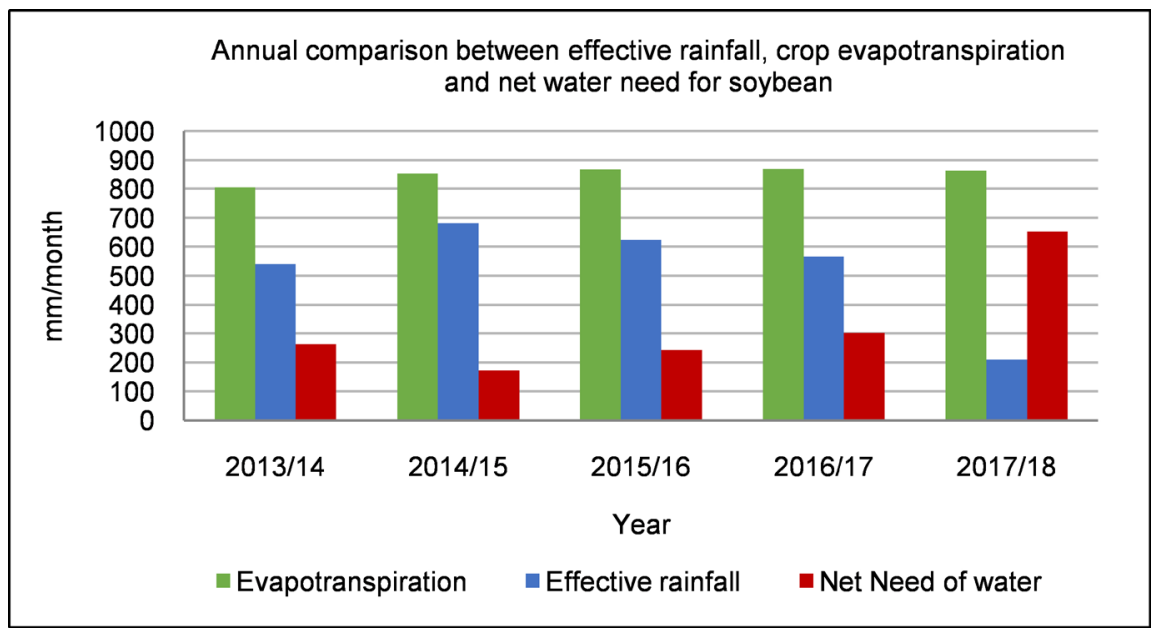

Figure 2. Annual comparison between effective rainfall, crop evapotranspiration and net water need for soybean.

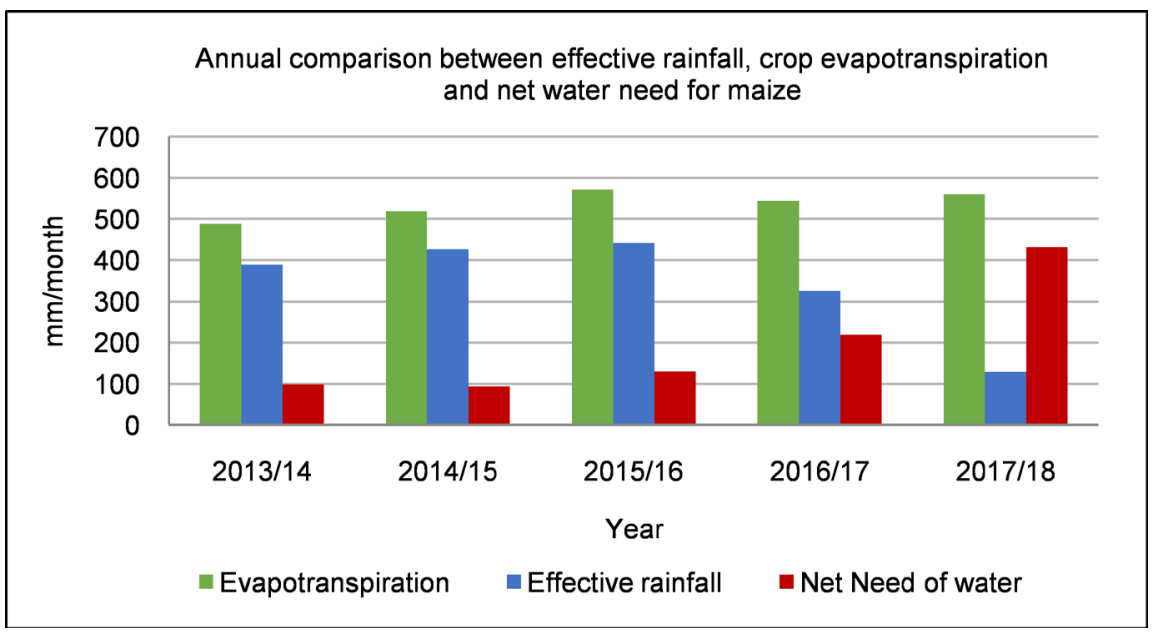

Figure 3. Annual comparison between effective rainfall, crop evapotranspiration and net water need for maize. 


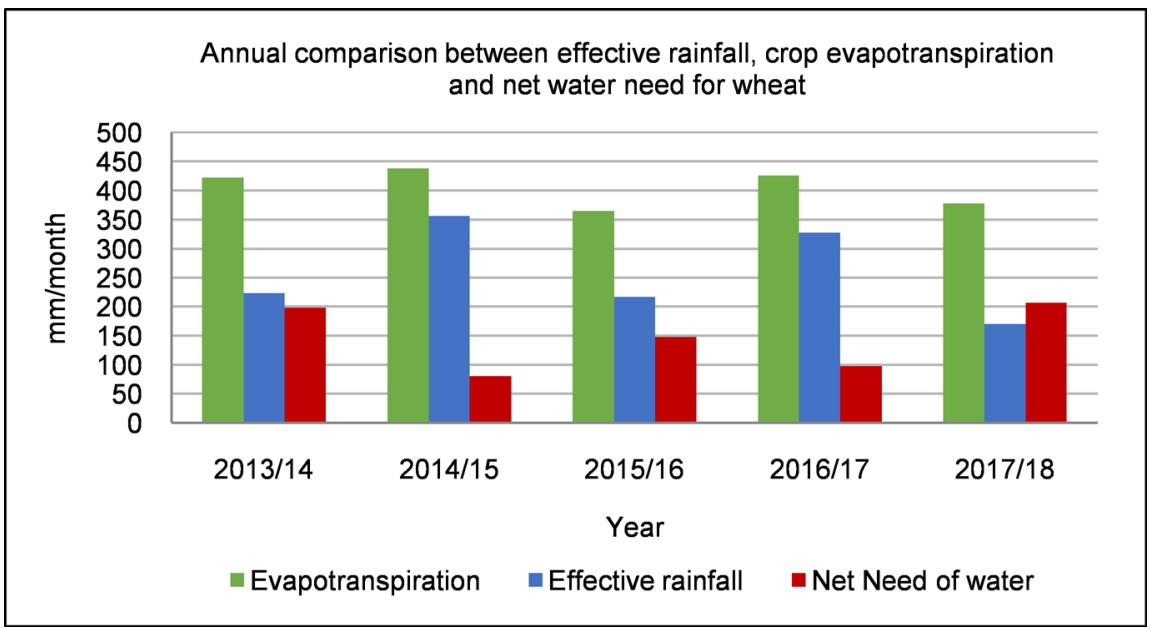

Figure 4. Annual comparison between effective rainfall, crop evapotranspiration and net water need for wheat.

\subsection{Green Water Footprint}

The average WF of soybean crop for the period 2013-2018 was $1,292 \mathrm{l} \cdot \mathrm{kg}^{-1}$. The highest value was in 2015, this being $1,530 \mathrm{l} \cdot \mathrm{kg}^{-1}$ and the lowest value in 2017, being $684 \mathrm{l} \cdot \mathrm{kg}^{-1}$. The results are shown in Table 1 and in graph 4 .

The average green WF of maize crop for 2013-2018 period was $3681 \cdot \mathrm{kg}^{-1}$, the highest value was in the 2015/16 growing season being $5261 \cdot \mathrm{kg}^{-1}$ and the lowest value was in the 2017/18 growing season being $1611 \cdot \mathrm{kg}^{-1}$. In this case, a strong variation in crop yields is observed along the growing seasons due to the low physiological capacity of the crop to adapt to environmental changes. However, this variation follows the variation of the rainfall. The results are shown in Table 2 and graph 5 .

The average green water footprint for wheat crop in the 2013-2017 period was $596 \mathrm{l} \cdot \mathrm{kg}^{-1}$, the highest value was in 2014 being $9131 . \mathrm{kg}^{-1}$ and the lowest value was in 2017 being $371 \mathrm{l} \cdot \mathrm{kg}^{-1}$. The results are shown in Table 3 and graph 6 . It should be noted that, in 2014, although rainfall was very abundant, the crop presented the lowest recorded yields. This could be due to the intense heat in October that affected the filling of the grains, especially in later batches, causing the presence of many small grains; added to this, abundant rains were concentrated during drying and harvesting, making these processes difficult (INTA, 2015).

\subsection{Grey water footprint}

The average grey WF for soybean for the 2013-2018 period was $96 \mathrm{l} \cdot \mathrm{kg}^{-1}$, with the highest value in 2017 being $121 \mathrm{l} \cdot \mathrm{kg}^{-1}$ and the lowest value in 2014 of 91 $1 \cdot \mathrm{kg}^{-1}$. This is directly related with the yield obtained in every growing season. The results are shown in Table 4 and graph 7.

The average grey water footprint for maize crop for the period 2013-2018 was $325 \mathrm{l} \cdot \mathrm{kg}^{-1}$ and the highest value was in 2017 being $371 \mathrm{l} \cdot \mathrm{kg}^{-1}$. The results are shown in Table 5 and graph 8. 
Table 1. Calculation of green WF for soybean for 2013-2018 period.

\begin{tabular}{cccccc}
\hline Growing Season & $2013-2014$ & $2014-2015$ & $2015-2016$ & $2016-2017$ & $2017-2018$ \\
\hline Effective precipitation (1/ha) & $5,410,840$ & $6,806,659$ & $6,244,446$ & $5,663,389$ & $2,093,906$ \\
Growing area (ha) & 193,450 & 192,560 & 206,596 & 174,750 & 186,770 \\
Average yield (kg/ha) & 4,010 & 4,569 & 4,081 & 4,020 & 3,063 \\
Green WF (l/kg) & 1,349 & 1,490 & 1,530 & 1,409 & 684 \\
\hline
\end{tabular}

Table 2. Calculation of green WF for maize for 2013-2018 period.

\begin{tabular}{cccccc}
\hline Growing Season & 2013-2014 & 2014-2015 & 2015-2016 & 2016-2017 & 2017-2018 \\
\hline Effective precipitation $\left(1 \cdot \mathrm{ha}^{-1}\right)$ & $3,892,497$ & $4,264,013$ & $4,421,300$ & $3,256,269$ & $1,289,802$ \\
Growing area (ha) & 12,650 & 27,800 & 22,620 & 43,950 & 44,211 \\
Average yield (kg.ha $\left.{ }^{-1}\right)$ & 9,000 & 10,500 & 8,400 & 10,400 & 8,000 \\
Green WF $\left(\mathrm{l} \cdot \mathrm{kg}^{-1}\right)$ & 432 & 406 & 526 & 313 & 161 \\
\hline
\end{tabular}

Table 3. Calculation of green WF for wheat for 2013-2018 period.

\begin{tabular}{cccccc}
\hline Growing Season & 2013-2014 & 2014-2015 & 2015-2016 & 2016-2017 & 2017-2018 \\
\hline Effective precipitation (1/ha) & $2,236,691$ & $3,562,484$ & $2,167,154$ & $3,277,426$ & $1,704,850$ \\
Growing area (ha) & 9,100 & 10,360 & 24,615 & 35,780 & 34,823 \\
Average yield (kg/ha) & 4,500 & 3,900 & 4,200 & 4,800 & 4,600 \\
Green WF (l/kg) & 497 & 913 & 516 & 683 & 371 \\
\hline
\end{tabular}

Table 4. Grey WF for soybean for 2013-2018 period.

\begin{tabular}{cccccc}
\hline Season & $2013-2014$ & $2014-2015$ & $2015-2016$ & $2016-2017$ & $2017-2018$ \\
\hline Yield (kg/ha) & 4,010 & 4,569 & 4,081 & 4,020 & 3,063 \\
Grey water footprint (l/kg) & 93 & 81 & 91 & 92 & 121 \\
\hline
\end{tabular}

Table 5. Grey WF for maize for 2013-2018 period.

\begin{tabular}{cccccc}
\hline Season & $2013-2014$ & $2014-2015$ & $2015-2016$ & $2016-2017$ & $2017-2018$ \\
\hline Yield (kg/ha) & 9,000 & 10,500 & 8,400 & 10,400 & 8,000 \\
Grey water footprint (1/kg) & 330 & 283 & 354 & 286 & 371 \\
\hline
\end{tabular}

Table 6. Grey WF for wheat for 2013-2018 period.

\begin{tabular}{cccccc}
\hline Season & $2013-2014$ & $2014-2015$ & $2015-2016$ & $2016-2017$ & $2017-2018$ \\
\hline Yield (kg/ha) & 4,500 & 3,900 & 4,200 & 4,800 & 4,600 \\
Grey water footprint (1/kg) & 635 & 733 & 680 & 595 & 621 \\
\hline
\end{tabular}


The average grey water footprint for wheat crop for the period 2013-2017 was $653 \mathrm{l} \cdot \mathrm{kg}^{-1}$, the highest value was in 2014 being $7331 \cdot \mathrm{kg}^{-1}$. The results are shown in Table 6 and graph 9.

\subsection{Water Footprint}

As can be seen in Table 7 and in graph 10, the average water footprint for soybean was $1,3881 \cdot \mathrm{kg}^{-1}$, with the highest value in the $2015 / 16$ growing seasons being $1,621 \mathrm{l} \cdot \mathrm{kg}^{-1}$. The lowest value was in the $2017 / 18$ growing season, this being $805 \mathrm{l} \cdot \mathrm{kg}^{-1}$.

The average water footprint for maize for the 2013-2018 period was $6931 . \mathrm{kg}^{-1}$, the highest value was in the $2015 / 16$ growing season being $880 \mathrm{l} \cdot \mathrm{kg}^{-1}$. The lowest value was in the 2017/18 growing season, this being $5331 \cdot \mathrm{kg}^{-1}$. The results are shown in Table 8 and graph 11.

The average water footprint for wheat crop for the 2013-2017 period was 1245 $1 \cdot \mathrm{kg}^{-1}$, the highest value was in the $2014 / 15$ season being $1,6461 \cdot \mathrm{kg}^{-1}$. The lowest value was in the $2017 / 18$ growing season, this being $9921 \cdot \mathrm{kg}^{-1}$. The results are shown in Table 9 and graph 12.

In the year 2017, the crop yield was according to the water availability, so the WF is the lowest of this series of years for the three crops in study.

\subsection{Global Water Footprint Data}

According to data published by Mekonnen and Hoekstra in 2011, in their publication "The Green, Blue and Gray Water Footprint of Crops and Derived Crop Products", the average WF for cereal crops was $1,6441 \cdot \mathrm{kg}^{-1}$ for the $1996-2005$ period. The WF for wheat was the largest $\left(1,827 \mathrm{l} \cdot \mathrm{kg}^{-1}\right)$ and the maize WF was the smallest one $\left(1,222 \mathrm{l} \cdot \mathrm{kg}^{-1}\right)$. The WF for the soybean crop was $2,145 \mathrm{l} \cdot \mathrm{kg}^{-1}$. The analysis of the partial and total results can be seen in Table 10 [16].

Table 7. WF calculation for soybean in the 2013-2018 period.

\begin{tabular}{cccccc}
\hline Growing Season & $2013 / 14$ & $2014 / 15$ & $2015 / 16$ & $2016 / 17$ & $2017 / 18$ \\
\hline Blue WF & 0 & 0 & 0 & 0 & 0 \\
Green WF & 1,349 & 1,490 & 1,530 & 1,409 & 684 \\
Grey WF & 93 & 81 & 91 & 92 & 121 \\
Total WF & 1,442 & 1,571 & 1,621 & 1,501 & 805 \\
\hline
\end{tabular}

Table 8. WF calculation for maize in the 2013-2018 period.

\begin{tabular}{cccccc}
\hline Growing Season & $2013 / 14$ & $2014 / 15$ & $2015 / 16$ & $2016 / 17$ & $2017 / 18$ \\
\hline Blue WF & 0 & 0 & 0 & 0 & 0 \\
Green WF & 432 & 406 & 526 & 313 & 161 \\
Grey WF & 330 & 283 & 354 & 286 & 371 \\
Total WF & 763 & 689 & 880 & 599 & 533 \\
\hline
\end{tabular}




\subsection{Annual Water Footprint Comparison}

The global average annual WF for the studied crops was published by Mekonnen and Hoekstra in 2011, in their publication "The Green, Blue and Gray Water Footprint of Crops and Derived Crop Products". The results of the comparison between both studies can be seen in Table 11, Table 12 and Table 13. A comparison of blue WF was not made as it was not calculated in this work for the reasons already explained.

Table 9. WF calculation for wheat in the 2013-2018 period.

\begin{tabular}{cccccc}
\hline Growing Season & $2013 / 14$ & $2014 / 15$ & $2015 / 16$ & $2016 / 17$ & $2017 / 18$ \\
\hline Blue WF & 0 & 0 & 0 & 0 & 0 \\
Green WF & 497 & 913 & 516 & 683 & 371 \\
Grey WF & 635 & 733 & 680 & 595 & 621 \\
Total WF & 1,132 & 1,646 & 1,196 & 1,278 & 992 \\
\hline
\end{tabular}

Table 10. Partial and total global average water footprints for soybean, maize and wheat crops.

\begin{tabular}{ccccc}
\hline \multirow{2}{*}{ Crop } & \multicolumn{4}{c}{ Water footprint $(1 / \mathrm{kg})$} \\
\cline { 2 - 5 } & Green WF & Blue WF & Grey WF & Total WF \\
\hline Soybean & 2,037 & 70 & 37 & 2,145 \\
Maize & 947 & 81 & 194 & 1,222 \\
Wheat & 1,277 & 342 & 207 & 1,827 \\
\hline
\end{tabular}

Table 11. Comparison between the global average green WF and the Pergamino average green WF for soybean, maize and wheat crops.

\begin{tabular}{ccc}
\hline Crop & Global Average Green WF & Pergamino Average Green WF \\
\hline Soybean & 2,037 & 1,292 \\
Maize & 947 & 368 \\
Wheat & 1,277 & 596 \\
\hline
\end{tabular}

Table 12. Comparison between the global average grey WF and the Pergamino average grey WF for soybean, maize and wheat crops.

\begin{tabular}{ccc}
\hline Crop & Global Average Grey WF & Pergamino Average Grey WF \\
\hline Soybean & 37 & 96 \\
Maize & 194 & 325 \\
Wheat & 207 & 653 \\
\hline
\end{tabular}


Table 13. Comparison between the global average WF and the Pergamino average WF for soybean, maize and wheat crops.

\begin{tabular}{ccc}
\hline Crop & Global Average Total WF & Pergamino Average total WF \\
\hline Soybean & 2,145 & 1,388 \\
Maize & 1,222 & 693 \\
Wheat & 1,827 & 1,249 \\
\hline
\end{tabular}

\section{Discussion}

\subsection{Evapotranspiration and Precipitation (2013-2018)}

The variation of the water footprint results depends on different factors. Among them we can mention the model used, the period in which evapotranspiration was calculated (annual or in the growth period of the crop), the growth period of the crop, the climate and soil conditions during this period, and the size from the observation surface. The variations of the WF between crops are mainly due to the differences they present in terms of their growth period and the nature of the harvested plant part. Also, each species has different physiological and metabolic mechanisms to face environmental variations. Generally, water footprint of crops is most sensitive to ET0 and Kc, followed by the crop calendar [20]. Also, Zhuo et al. reported that Blue water footprints are more sensitive to input variability than green water footprints [20]. In this work, WF was measured based on the effective precipitation, which is closely linked to crop evapotranspiration, for this reason the main variations are due to the difference in Crops Kc between crops, which directly influences the useful water that the crop received.

The variation in effective rainfall between years is mainly due to the variation in rainfall that occurred. While in 2014 there were abundant rains, in 2017 there were long periods of drought, which allowed the study of crops in a wide range of conditions. The WF of the 3 studied crops are directly related to their respective effective rainfall, copying the variations that occurred over the years. In the studied period none of the 3 crops received enough water to cover their net need. This shows that rain fed crops in this area only occasionally see their water demand covered; which implies that a part of the potential yield is not reached.

\subsection{Annual Water Footprint}

The green WF obtained per year for each crop is the product of the relationship between yield and effective rainfall (affected by ETc). The crop yields were in accordance with the water availability and therefore with the crop evapotranspiration. This is consistent with the Doorembos and Kassan (1979) model, in which the relative yield is related to the relative Evapotranspiration and the Ky factor for each crop and each phenological stage they are in. This factor expresses the relationship between production and use of water by a crop. This explains the independence between the WF magnitude and the water deficit that 
occurred in the studied period. Both the yield and the effective precipitation are affected according to the Ky of the crop, so they vary in the same way. In all cases, the WF in 2017 was the lowest in the entire series, this is due to the drought that occurred in that period. The wheat crop was the one that suffered the greatest variation between years. This was due to the fact that it presented similar yields in all seasons, but not similar effective rainfall; this cereal presents physiological compensation mechanisms that dampen the variation in yield. The 2014 green WF was the largest in this series for this crop and is due to low yield despite abundant rainfall. This can be explained by a severe rust attack that year, added to the concentration of rains at harvest time, which delayed and affected this process. The maize crop presented its highest WF in 2015 due to the combination of high effective rainfall and relatively low yields. These low yields are not correlated with water availability and can be attributed to the concentration of rainfall during the grain drying and harvesting period. The grey water footprint, in each studied crop, is similar for all campaigns. This is due to the fact that the technology used does not vary in a significant way from year to year and also, it is adjusted to climate expectations. The grey WF was calculated from the pollutant load, the environmental quality standard, the natural concentration of the pollutant and the crop yield. The first 3 terms are constant, therefore, since yield performance is the only variable modified between growing seasons, the observed differences can be assigned to it. The grey WF of the soybean crop was the lowest. This is due to the low amounts of nitrogen applied in its fertilization. Wheat grey WF was the highest of the 3 crops, mainly because a large amount of nitrogen is applied per hectare, added to the fact that the biomass harvested from the crop is less than that of maize. The sum of grey WF and green WF gives as a result the total water footprint per season for each crop. The proportions of grey WF and green WF for wheat and maize crops are similar, while the WF of soybean crops is almost entirely explained by its green WF since, as seen previously, its grey WF is very small. The total WF of soybeans, maize and wheat follow the variation of rainfall, since these, in turn, condition the crop yield. Soybean and wheat crops present higher water footprints than maize. This can be explained mainly by the biomass yielded of each crop per hectare. This is conditioned by its morphology, the genetics used and the technology. While the yields of maize are between $8 \mathrm{tn} \cdot \mathrm{ha}^{-1}$ and $10 \mathrm{tn} \cdot \mathrm{ha}^{-1}$, those for soybeans and wheat are not higher than $4.5 \mathrm{tn} \cdot \mathrm{ha}^{-1}$ and $4.8 \mathrm{tn} \cdot \mathrm{ha}^{-1}$ respectively. Our results are in concordance with those of Tuninetti et al. as they reported that wheat has a high water productivity, maize is the most efficient crop in terms of water consumption and soybean is the most water consuming crop per tons of product [21].

\subsection{Global Water Footprint}

In order to compare the WF calculated in this work with previously conducted studies, the research work by Mekonnen and Hoekstra [14] was selected since it 
estimated the WF of crops at a global level, making a marked distinction between the components of the WF. The estimates obtained in this work in comparison with previous studies are in orders of similar magnitudes. Although there are differences in the applied models and the assumptions made, the models coincide in the predominance of green WF in the production of soybean, maize and wheat crops. The water balance estimation model used in both studies was the same. The ETc depends on the climate (which determines the ETo), the characteristics of the crop and the availability of water in the soil. The grey WF was calculated based on the nitrogen fertilization in both works. Mekonnen and Hoekstra calculated the blue water footprint for the studied crops by using two different soil water balance scenarios, proposed by Hoekstra et al. in 2008 [22]. The first soil water balance scenario was carried out assuming there was no irrigation, unlike the second soil water balance scenario where it was assumed that the actual amount of irrigation was sufficient to meet the irrigation requirements. In both scenarios, the same cultivation parameters were applied (such as rooting depth under irrigation conditions). This model assumes that the green WF of irrigated crops is equal to the actual evapotranspiration of the crop as calculated in the first scenario; Therefore, the blue WF of the crop was equal to the water use of the crop during the growing period as simulated in the second scenario minus the green WF as estimated in the first scenario. In the work used as reference for comparison, the authors affected the growth and yield of the crops by water stress using a linear relationship between yield and crop evapotranspiration proposed by Doorenbos and Kassam in 1979 [23]. This model use monthly long-term average reference evapotranspiration data obtained from FAO and monthly precipitation values from CRU-TS-2.1 for the calculation of global average annual WF. The cultivation surface was obtained from Monferda et al. (2008) [24]. For countries whose data from the Monfreda grid are unknown [24], they used the Grid 5 database MICRA2000 as described in Portmann et al. (2010) to fill in the missing data [25]. They also added the harvested crop areas available in grid format at the national level and scaled them to fit the national average crop harvest areas for the period 1996-2005 obtained from FAO (2008a). To determine the maximum yield values for each crop, the corresponding national average yield values were multiplied by a factor of 201.2 [26]. They calculated the real yields per grid cell, using the average for the entire country and comparing it with the national average yield data (for the period 1996-2005) from FAO (2008a) [27]. Finally, they scaled the calculated yield values to fit FAO's national average of yield data. In this work, by evaluating a smaller area and having access to all the data, it was not necessary to make generalizations at the national level or to use a grid cell system. Sun, S. K. et al. (2013), in Beijing, China (1978-2008), using the CROPWAT 8.0 model, obtained an average maize footprint of $1,031 \mathrm{~L} \cdot \mathrm{kg}^{-1}$ (56\% corresponding to green WF, $25 \%$ blue WF and 19\% to gray WF). The value of the green footprint almost duplicates the one estimated in this study. However, the gray WF of maize is 
similar to the world average and a third lower than that calculated in this work [28].

\subsection{Water Footprint Comparison}

The differences in results between the average annual water footprints obtained in this work for each crop and the one calculated by Mekonnen and Hoekstra may be due to a number of reasons. Most of the difference could be due to the fact that Mekonnen and Hoekstra calculate the blue WF and add it to the total water footprint. Nevertheless, in Pergamino, the environmental conditions allow to grow rainfall crops obtaining good yields without the need for irrigation, so this is not a common practice, which leads to the assumption that the blue WF is null. However, Mekonen and Hoekstra, in 2020, showed that about 57\% of the global blue WF of crop production is unsustainable because it goes beyond the available renewable water resources, violating the environmental flow criterion, and needs to be fully reduced in order to alleviate the blue water scarcity across the globe. Particularly, about $27 \%$ of the unsustainable portion of global blue WF is due to the production of wheat. These findings coincide with the results of high efficiency rainfed production, which nullifies the calculation of blue WF and is based mainly on the green WF [29]. These results also explain the great difference between the total WF of wheat calculated in Pergamino with respect to the global average WF of wheat. Following the same line, Rockstrom and Barron [2007], have shown that there is a great opportunity to improve water productivity through the improvement of yield levels within the available water balance in rainfed agriculture, without requiring additional blue water resources. [30].

Fernandez (2014) estimated an average value of rainfed water footprint in two sites in the province of Buenos Aires (Pergamino and Quequén) of $631 \mathrm{~L} \cdot \mathrm{kg}^{-1}$ [31]. This value is very similar to the one estimated in this work.

Another difference between the results obtained in this work and those obtained by Mekonnen and Hoekstra could be explained by the fact that in this work effective precipitation was used to calculate the WF, since it is considered that not all the rainfall is useful for crop growing since it can drain rather than infiltrate in the soil profile. Considering all rain water as useful water can lead to overestimations of the result. Also, Mekonnen and Hoekstra used national average yields by country to make their calculations. This generalization may overestimate the result due to variation between regions within a country.

Although the total WF obtained in this work is lower than the global average WF, the grey WF calculated for the crops under study is much higher than their global average. This may be because Mekonnen and Hoekstra used generalized nitrogen application rates at a country level. In Argentina there is a lot of variation throughout the territory, so a national average application rate cannot be assumed. Furthermore, the aforementioned authors use the maximum nitrate level allowed by the OMS and the EU, which is $50 \mathrm{mg} \cdot \mathrm{l}^{-1}$. This is $5 \mathrm{mg} \cdot \mathrm{l}^{-1}$ higher 
than what is allowed in Argentina, which reduces their grey WF calculation. Finally, due to the lack of global data, the authors of the reference work assume that the natural nitrates of the aquifers are equal to zero, which underestimates the real number.

Since all measurements depend on a large set of model assumptions and parameter values and data sets used, it is difficult to attribute the results to specific factors. The quality of the data used defines the precision of the results, and all studies suffer the same kinds of limitations in terms of data availability and quality, although these are handled in different ways. These factors determine that the comparisons between works carried out at different times and places are relative since they depend on the quality of local data collection and it is difficult to homogenize methodologies. The results presented in this work allow to open a space for discussion about the importance of water and its efficient use, and, thus, to become aware of the productive management of a non-renewable natural resource. It is important to value the natural resources of the region and the comparative advantages that they bring us. These benefits would cease to be significant over time if resources are not managed correctly. Green water has in general a lower opportunity cost than blue water, it is due to its high unpredictability and the lower feasibility of alternative uses, therefore it would be desirable to encourage their use "in situ" through appropriate cultural works. Practices such as fallow, no tilling and planting across the maximum slope to reduce surface runoff can maximize the efficiency of green water use [32].

\section{Conclusions}

The total annual mean values of WF for soybean, corn and wheat crops for the period 2013-2018 in the district of Pergamino, province of Buenos Aires, are lower than the world average reference values. WF of the crops under study is mainly composed of the green WF since the production is in dry land. This highlights the importance of the use of rainwater and stored water in the soil profile in the study region and the need for a rational management of rainwater resources, minimizing surface runoff and water erosion. The results of this work coincide with previous studies, in which green water plays a central role in production at a national level; Argentina is one of the countries considered net exporters of water in international trade.

The grey fraction of WF for the 3 crops under study was notably higher than the world average, despite the fact that the methodology used only includes only fertilizers and no other products such as herbicides and insecticides. These results indicate the need to review some of the agricultural fertilization practices that are carried out in the fields to achieve a more efficient use of chemicals.

The average annual WF for the study crops in the Pergamino district is considerably lower compared to the global average annual WF. This indicates a good correlation between the performance of the crop and the water supply along the cycle, which denotes a high productive efficiency. A lower WF, although it indi- 
cates greater efficiency, does not indicate a lower environmental impact since it does not ensure that there is no risk of water deficit in the evaluated basin.

The net water needs are not reached in any year, for any of the 3 crops. This indicates the existence of a limitation to the potential yield of the varieties. The use of pivot or subsurface drip irrigation equipment could be evaluated in critical stages of crops that are under water deficit, to meet the net needs and reduce the yield gap.

There are some uncertainties in the estimation of the water footprint since, although the data is accurate, the models used are simple and some assumptions were made when generalizing certain parameters:

- Grey WF estimation model does not consider the local factors that influence the precise leaching and runoff rates of nitrates, such as rainfall intensity, soil characteristics, terrain slopes, and the amount of nitrogen already mineralized. in the upper layer of the soil.

- Common practices such as rotation schemes could not be considered because they are not uniform in the area, which makes generalization impossible.

- The technology used was assumed for the entire region based on its prevalence.

- The soil storage capacity was carried out according to the dominant soil type in the region, but it is known that there are variations in the extension of the surface that can present different levels of water retention.

Based on the results obtained, it is proposed to adopt norms and standards that use WF as an indicator in the production of extensive crops, achieve comparative evaluations in the sector and between the different regions of the country, establish reduction goals at a national level as public policy and build collective action strategies at a basin level to minimize the risk of water deficit. This indicator can be used to know the productivity limit of a territory and optimize the use of the resource to improve yields and reduce the gap between actual and potential yield. Water footprint is an indicator that has not extended diffusion in Argentina; It should be used for the characterization of different productive managements with the objective of making field management decisions taking into account the efficient use of water resources. It is very important to use the water pressure index, which indicates the relationship between available green water and green WF, to determine the environmental impact of expanding the agricultural frontier and intensifying production. Two processes in constant evolution in recent years.

\section{Conflicts of Interest}

The authors declare no conflicts of interest regarding the publication of this paper.

\section{References}

[1] Postel, S.L. (2000) Entering an Era of Water Scarcity: The Challenge Ahead. Ecological Applications, 10, 941-948. 
https://doi.org/10.1890/1051-0761(2000)010[0941:EAEOWS]2.0.CO;2

[2] Gerbens-Leenes, W., et al. (2009) The Water Footprint of Bioenergy. PNAS, 106, 10219-10223. https://doi.org/10.1073/pnas.0812619106

[3] Hoekstra, A.Y., et al. (2008) Globalization of Water Sharing the Planet's Freshwater Recourses. Blackwell, Oxford.

[4] Mekonnen, M., et al. (2014) Water Footprint Benchmarks for Crop Production: A First Global Assessment. Ecological Indicators, 46, 214-223. https://doi.org/10.1016/j.ecolind.2014.06.013

[5] Hoekstra, et al. (2011) The Water Footprint Assessment Manual: Setting the Global Standard. Earthscan, London.

[6] Ministerio de agricultura, ganadería y pesca de la republica Argentina (2018) Censo nacional agropecuario.

https://www.indec.gob.ar/ftp/cuadros/economia/cna2018_resultados_preliminares. pdf

[7] FAO (2015) Estudio del potencial de la ampliación del riego en Argentina. Organización de las Naciones Unidas para la Alimentación y la Agricultura; Ministerio de Agricultura, Ganadería y Pesca de Argentina. Buenos Aires, Argentina.

[8] Hoekstra, A.Y. and Chapagain, A.K. (2006) Water Footprints of Nations: Water Use by People as a Function of Their Consumption Pattern. In: Integrated Assessment of Water Resources and Global Change, Springer, Dordrecht, 35-48. https://doi.org/10.1007/978-1-4020-5591-1_3

[9] Municipalidad de Pergamino (2015) Información pública. http://www.pergamino.gob.ar

[10] Portela, S., Andriulo, A., Sasal, M.C., Mary, B. and Jobbgy, E. (2006) Fertilizer vs. Organic Matter Contribution to Nitrogen Leaching in Cropping Systems of the Pampas: 15N Applications in Field Lysimiters. Plant and Soil, 289, 265-277. https://doi.org/10.1007/s11104-006-9134-Z

[11] Uriburú Quirno, M., Damiano, F., Borus, J., Lozza, H. and Villareal, J. (2010) Modelacion hidrologica en modo actualizado del Arroyo Pergamino. Congreso Internacional de Hidrologia de Llanuras, Azul, 21-24 September 2010, 8 p.

[12] Centro de estudios Sociales y ambientales (2004) Estudio de Caso: Pergamino. Informe Final IAI-ENSO Argentina. Cap. IV, 35 p.

[13] Puentes, M.I. and Casas, R. (2009) Regionalización de los suelos de la Provincia de Buenos Aires. limitaciones a la productividad agropecuaria. Informe sobre desarrollo humano en la provincia de Buenos Aires 2008-2009. EUDEBA, Buenos Aires, 121-147.

[14] Mekonnen, M.M. and Hoekstra, A. (2011) The Green, Blue and Grey Water Footprint of Crops and Derived Crop Products. Hydrology and Earth System Sciences Discussions, 8, 763-809. https://doi.org/10.5194/hessd-8-763-2011

[15] Dastane (1974) Precipitación efectiva en la agricultura de regadío. Ed. FAO, Roma.

[16] Mekonnen, M.M. and Hoekstra, A.Y. (2011) National Water Footprint Accounts: The Green, Blue and Grey Water Footprint of Production and Consumption. Value of Water. Research Report Series (50). https://doi.org/10.5194/hessd-8-763-2011

[17] Bolsa de cereales (2018) Informes publicados. http://www.bolsadecereales.com/descargar-documento2-196/retaa-84372a6c91d530 $35 \mathrm{~d} 612 \mathrm{~d} 39 \mathrm{c} 124 \mathrm{bb} 7 \mathrm{fb}$

[18] Código Alimentario Argentino (2012) Capítulo XII: Bebidas hídricas, agua y agua gasificada. Ley 18.284. Argentina. 
http://www.anmat.gov.ar/alimentos/códigoa/CAPITULO_XII.pdf

[19] ACUMAR (2020) Indicadores.

https://www.google.com/url? sa=t\&rct=j\&q=\&esrc=s\&source=web\&cd=\&cad=rja\& uact=8\&ved=2ahUKEwiEzfahxbjvAhXbK7kGHZHVDsQQFjACegQIAxAD\&url=h ttps\%3A\%2F\%2Fwww.acumar.gob.ar\%2Fwp-content\%2Fuploads\%2F2016\%2F12\% 2F24.-2020-04-ANEXO.pdf\&usg=AOvVaw3ksu0AIKDAmek96Zj-IRP8

[20] Zhuo, L., Mekonnen, M.M. and Hoekstra, A.Y. (2014) Sensitivity and Uncertainty in Crop Water Footprint Accounting: A Case Study for the Yellow River Basin. $\mathrm{Hy}$ drology and Earth System Sciences, 18, 2219-2234.

https://doi.org/10.5194/hess-18-2219-2014

[21] Tuninetti, M., Tamea, S., D’Odorico, P., Laio, F. and Ridolfi, L. (2015) Global Sensitivity of High-Resolution Estimates of Crop Water Footprint. Water Resources Research, 51, 8257-8272. https://doi.org/10.1002/2015WR017148

[22] Hoekstra, A.Y., et al. (2008) Globalization of Water Sharing the Planet's Freshwater Recourses. Blackwell, Oxford.

[23] Doorenbos, J. and Kassam, A.H. (1979) Respuesta del rendimiento de los cultivos al agua. Estudios FAO Riego y Drenaje No 33, Roma.

[24] Monfreda, C., Ramankutty, N. and Foley, J.A. (2008) Farming the Planet: 2. Geographic Distribution of Crop Areas, Yields, Physiological Types, and Net Primary Production in the Year 2000. Global Biogeochemical Cycles, 22, GB1022. https://doi.org/10.1029/2007GB002947

[25] Portmann, F.T., Siebert, S. and Doll, P. (2009) Mirca2000-Global Monthly Irrigated and Rainfed Crop Areas around the Year 2000: A New High-Resolution Data Set for Agricultural and Hydrological Modelling. Global Biogeochemical Cycles, 24, GB1011. https://doi.org/10.1029/2008GB003435

[26] Reynolds, C.A., Yitayew, M., Slack, D.C., Hutchinson, C.F., Huete, A. and Petersen, M.S. (2000) Estimating Crop Yields and Production by Integrating the FAO Crop Specific Water Balance Model with Real-Time Satellite Data and Ground-Based Ancillary Data. International Journal of Remote Sensing, 21, 3487-3508. https://doi.org/10.1080/014311600750037516

[27] FAOSTAT On-Line Database (2008) Food and Agriculture Organization, Rome. http://faostat.fao.org

[28] Sun, S.K., Wu, P.T., Wang, Y.B. and Zhao, X.N. (2013) Temporal Variability of Water Footprint for Maize Production: The Case of Beijing from 1978 to 2008. Water Resources Management, 27, 2447-2463. https://doi.org/10.1007/s11269-013-0296-1

[29] Mekonnen, M.M. and Hoekstra, A.Y. (2020) Sustainability of the Blue Water Footprint of Crops. Advances in Water Resources, 143, Article ID: 103679. https://doi.org/10.1016/j.advwatres.2020.103679

[30] Rockstrom, J. and Barron, J. (2007) Water Productivity in Rainfed Systems: Overview of Challenges and Analysis of Opportunities in Water Scarcity Prone Savannahs. Irrigation Science, 25, 299-311. https://doi.org/10.1007/s00271-007-0062-3

[31] Fernandez, P. (2014) Water Consumptions in Different Crop Sequences in the Pampean Region to Analyse the Possibilities to Integrate More Maize in Crop Rotation to Produce Biofuels. Facultad de Agronomía. UBA, Buenos Aires.

[32] Alvarez, A., et al. (2016) Green and Blue Water Footprint of Corn (Zea mayz) Production in Central and Northeastern Provinces of Argentina. Rev. Fca Uncuyo, 48, 161-177. 